\title{
Wspólna Polityka Rolna po 2013 r. - wybrane problemy prawne ${ }^{2}$
}

Wprowadzona od 2013 r. reforma Wspólnej Polityki Rolnej (WPR) przedstawia nowe perspektywy finansowe dla rolnictwa preferując rolnictwo zrównoważone działające $\mathrm{w}$ zgodzie $\mathrm{z}$ zasadami ochrony przyrody. $\mathrm{W}$ tym celu $\mathrm{w}$ instrumentach finansowania WPR stworzono wiele nowych wymogów i zachęt dla rolników. Zmodyfikowano także niektóre dotychczasowe mechanizmy dostosowując je do nowych celów WPR oraz możliwości budżetowych Wspólnoty. Poniżej zostaną przedstawione najważniejsze zagadnienia prawne w zakresie implementacji i stosowania nowych przepisów dotyczących finansowania WPR. Zaprezentowany zostanie także stan dotychczasowych prac legislacyjnych nad realizacją przyjętych rozwiązań europejskich.

Główne problemy prawne i praktyczne WPR po reformie z 2013 r. ogniskują wokół kilku zagadnień: systemu płatności bezpośrednich, kwotowania produkcji mleka, czy polityki zazieleniania, która ma towarzyszyć nowemu systemowi płatności bezpośrednich.

Współczesna polska polityka rolna w dużej części dostosowana jest do Wspólnej Polityki Rolnej, w tym jej reformy z 2013 r. ${ }^{3}$ Oznacza to, że ocena zmian WPR jest także oceną krajowej polityki rolnej. Polski rząd w dużej mierze realizuje WPR. W zakresie krajowej polityki rolnej prowadzi działania dotyczące ubezpieczeń rolników, podatków, spraw związanych z kształtowaniem ustroju rolnego ${ }^{4}$ oraz funkcjonowania rynków rolnych, które nie są objęte wspólnotową regulacją.

1 Uniwersytet Warszawski.

2 Badania zostały sfinansowane ze środków Narodowego Centrum Nauki przyznanych w ramach finansowania stażu po uzyskaniu stopnia naukowego doktora na podstawie decyzji numer DEC-2012/04/S/HS5/00338. W artykule wykorzystano materiały autora będące częścią raportu krajowego na Europejski Kongres Prawa Rolnego w Poczdamie w 2015 r.

3 A. Jurcewicz, Wspólna Polityka Rolna Unii Europejskiej, [w:] Prawo rolne, P. Czechowski (red.), Warszawa 2011, s. $97-100$.

4 P. Czechowski, A. Niewiadomski, Obszary wiejskie a planowanie przestrzenne, [w:] „Studia luridica Agraria” 2012, t. X, s. 227-238. 
Obecnie, w ramach realizowanej polityki rolnej wypracowywane są instrumenty prawne, ${ }^{5}$ które pozwolą na zrealizowanie określonych w regulacjach europejskich celów. ${ }^{6}$ Wydawane są także rozporządzenia ministerialne, które określają warunki uzyskiwania pomocy. ${ }^{7}$ Główny cel działań skupia się na jak najlepszym rozdysponowaniu środków europejskich i budżetowych $\mathrm{w}$ ramach realizacji zadań WPR. ${ }^{8}$

Z punktu widzenia krajowej polityki rolnej wprowadzone zmiany oceniane są pozytywnie, tym bardziej że polskie rolnictwo w dużej mierze jest tradycyjne, co pozwala na wypełnienie wymogów stawianych w WPR po 2013 r. Należy jednak mieć pewne obawy, czy ta generalna pozytywna ocena nie będzie pomniejszona o efekty niektórych nowych rozwiązań prawnych, jak chociażby konieczność dywersyfikacji upraw. Koegzystencja europejskiej i krajowej polityki rolnej powoduje, że ta druga ma charakter komplementarny w stosunku do WPR. ${ }^{9}$ Krajowa polityka rolna jest realizowana w tych obszarach, które pozostają poza zainteresowaniem WPR.

Polski rząd przyjął szereg stanowisk dotyczących zarówno reformy WPR z 2013 r., jak też i wizji WPR w przyszłości. ${ }^{10}$ Do najważniejszych dokumentów można w tym zakresie zaliczyć:

Stanowisko Rządu RP do pakietu propozycji legislacyjnych dla WPR na lata 2014-2020 (przyjęte w kwietniu 2012 roku); ${ }^{11}$ Stanowisko Rządu RP w sprawie przyszłości Wspólnej Polityki Rolnej po 2013 roku (dokument kierunkowy z 2009

S. Prutis, „Dobór instrumentów prawnych służących wsparciu rozwoju obszarów wiejskich”, [w:] „Studia luridica Agraria 2009, t. VII, s. 192-203; T. Kurowska, Założenia konstrukcyjne umowy przyznania pomocy z Europejskiego Funduszu Rolnego na rzecz Rozwoju Obszarów Wiejskich, „Studia luridica Agraria” 2009, t. VII, s. 163-178. http://www.minrol.gov.pl/Informacje-branzowe/WPR-po-2013-roku

M.in. można do nich zaliczyć rozporządzenie Ministra Rolnictwa i Rozwoju Wsi z dnia 8 maja 2015 r. w sprawie szczegółowych warunków i trybu przyznawania pomocy w ramach działania „Inwestycje w rozwój obszarów leśnych i poprawę żywotności lasów" objętego Programem Rozwoju Obszarów Wiejskich na lata 2014-2020 (Dz.U. poz. 655); rozporządzenie Ministra Rolnictwa i Rozwoju Wsi z dnia 18 marca 2015 r. w sprawie szczegółowych warunków i trybu przyznawania pomocy finansowej w ramach działania „Działanie rolnośrodowiskowo-klimatyczne” objętego Programem Rozwoju Obszarów Wiejskich na lata 2014-2020 (Dz.U. poz. 765); rozporządzenie Ministra Rolnictwa i Rozwoju Wsi z dnia 13 marca 2015 r. w sprawie szczegółowych warunków i trybu przyznawania pomocy finansowej w ramach działania „Rolnictwo ekologiczne” objętego Programem Rozwoju Obszarów Wiejskich na lata 2014-2020 (Dz.U. poz. 370); rozporządzenie Ministra Rolnictwa i Rozwoju Wsi z dnia 13 marca 2015 r. w sprawie szczegółowych warunków i trybu przyznawania pomocy finansowej w ramach działania „Płatności dla obszarów z ograniczeniami naturalnymi lub innymi szczególnymi ograniczeniami” objętego Programem Rozwoju Obszarów Wiejskich na lata 2014-2020 (Dz.U. poz. 364). J. Wilkin, Wielofunkcyjność rolnictwa - konceptualizacja i operacjonalizacja zjawiska, „Wieś i Rolnictwo” 2009, nr 4, s. 4-29.

A.Z. Nowak, A. Niewiadomska, Wpływ funduszy strukturalnych na wzrost konkurencyjności polskiego rolnictwa - wybrane aspekty ekonomiczne, „Studia luridica Agraria” 2012, t. X, s. 307-325; P. Czechowski, A. Niewiadomski, Wpływ funduszy strukturalnych na wzrost konkurencyjności polskiego rolnictwa - aspekty prawne, „Studia luridica Agraria" 2012, t. X, s. 326-334.

10 W. Józwiak, W. Michna, Z. Mirkowska, Procesy zachodzące w polskim rolnictwie w latach 1990-2010 i pożądana wizja rolnictwa w 2020 roku - zagadnienia wybrane, Warszawa 2011; W. Poczta, Wspólna Polityka Rolna po 2013 roku - wizja zmian, [w:] A. Czyżewski, W. Poczta (red.), Projekty inwestycyjne w agrobiznesie a zasady Wspólnej Polityki Rolnej po 2013 roku, Poznań 2011.

11 http://www.minrol.gov.pl/content/download/35469/198140/version/1/file/00_www_OG\%C3\%93LNA\%20 OCENA\%20PAKIETU\%20i\%20zalozenia\%20stanowiska\%20RP.pdf 
roku); ${ }^{12}$ Ogólna ocena pakietu legislacyjnego WPR na lata 2014-2020 i założenia do Stanowiska Rządu RP ${ }^{13}$ Stanowisko Rządu RP do projektu rozporządzenia Parlamentu Europejskiego i Rady ustanawiającego przepisy dotyczące płatności bezpośrednich dla rolników na podstawie systemów wsparcia w ramach wspólnej polityki rolnej (COM(2011)625); ${ }^{14}$ Stanowisko Rządu RP do projektu rozporządzenia Parlamentu Europejskiego i Rady ustanawiającego wspólną organizację rynków produktów rolnych (,rozporządzenie o jednolitej wspólnej organizacji rynków”) (COM(2011)626). ${ }^{15}$ Wykaz innych stanowisk i opinii rządu polskiego w sprawie przyszłości WPR umieszczono na stronach internetowych Ministerstwa Rolnictwa i Rozwoju Wsi. ${ }^{16}$

Zgodnie z tymi dokumentami „,w opinii Rządu RP Wspólna Polityka Rolna także po 2013 r. będzie odgrywać kluczową rolę w zapewnieniu w UE: bezpieczeństwa żywnościowego, zrównoważonego rozwoju rolnictwa i obszarów wiejskich, równych warunków konkurencji na jednolitym rynku rolnym, a także silnej pozycji konkurencyjnej UE na globalnym rynku rolnym. [...] Zdaniem Rządu RP, aby zapewnić skuteczność i efektywność WPR w realizacji powyższych zadań w przyszłości kolejne zmiany tej polityki powinny: (i) zachować w pełni jej wspólnotowy charakter, w szczególności w wymiarze finansowym, zapewniając równe warunki konkurencji na jednolitym rynku UE, (ii) powiązać poziom i dystrybucję wsparcia finansowego poszczególnych działań, $\mathrm{w}$ tym $\mathrm{w}$ zakresie wsparcia bezpośredniego $\mathrm{z}$ aktualnymi i przyszłymi celami, co m.in. wymaga odejścia od historycznych pułapów (kopert) płatności bezpośrednich odzwierciedlających intensywność i poziom produkcji rolnej w poszczególnych państwach członkowskich sprzed kilkunastu lat, a także (iii) ograniczyć koszty wdrożeniowe zarówno po stronie instytucji UE, państw członkowskich, jak i samych beneficjentów, co wymaga dalszego uproszczenia tej polityki. Przyszła WPR musi być zrozumiała dla rolników, a także dla podatników i bez jej radykalnego uproszczenia nie będzie to możliwe". ${ }^{17}$

Obecnie trwają prace legislacyjne nad wdrożeniem regulacji europejskich i wydania aktów wykonawczych, które pozwoliłyby na aplikowanie o pomoc przez rolników. Dotychczas wydano w zakresie płatności bezpośrednich: ustawę z dnia 5

http://www.minrol.gov.pl/pol//nformacje-branzowe/WPR-po-2013-roku/Aktualnosci-WPR-po-2013-roku/Stanowisko-Rzadu-RP-w-sprawie-przyszlosci-Wspolnej-Polityki-Rolnej-po-2013-roku

$13 \mathrm{http://www.minrol.gov.pl/pol//nformacje-branzowe/WPR-po-2013-roku/Aktualnosci-WPR-po-2013-roku/Stanowi-}$ sko-Rzadu-RP-do-Komunikatu-KE

14 http://www.minrol.gov.pl/content/download/35470/198148/version/1/file/01_www_PLATNOSCI_stanowisko\%20 RP_\%20COM_2011_625.pdf

15 http://www.minrol.gov.pl/content/download/35471/198152/version/1/file/02_www_RYNKI_stanowisko\%20RP_ COM_2011_626.pdf

16 http://www.minrol.gov.pl/pol//nformacje-branzowe/WPR-po-2013-roku/Aktualnosci-WPR-po-2013-roku/Informacja-na-temat-stanowiska-rzadu-w-sprawie-WPR-po-2013-r

17 Ogólna ocena pakietu legislacyjnego WPR na lata 2014-2020 i założenia do Stanowiska Rządu RP, s. 1-5. 
lutego 2015 r. o płatnościach w ramach systemów wsparcia bezpośredniego; ${ }^{18}$ rozporządzenie Ministra Rolnictwa i Rozwoju Wsi z dnia 6 marca 2015 r. w sprawie elementów krajobrazu uznawanych za część kwalifikującego się obszaru działki rolnej oraz ich szerokości; ${ }^{19}$ rozporządzenie Ministra Rolnictwa i Rozwoju Wsi z dnia 6 marca 2015 r. w sprawie gatunków drzew, których uprawa stanowi zagajnik o krótkiej rotacji, oraz maksymalnego cyklu zbioru dla każdego z tych gatunków drzew; ${ }^{20}$ rozporządzenie Ministra Rolnictwa i Rozwoju Wsi z dnia 6 marca 2015 r. w sprawie określenia maksymalnego zagęszczenia drzew; ${ }^{21}$ rozporządzenie Ministra Rolnictwa i Rozwoju Wsi z dnia 6 marca 2015 r. w sprawie okresu obliczania udziału różnych upraw w celu dywersyfikacji upraw; ${ }^{22}$ rozporządzenie Ministra Rolnictwa i Rozwoju Wsi z dnia 9 marca 2015 r. w sprawie norm w zakresie dobrej kultury rolnej zgodnej z ochroną środowiska; ${ }^{23}$ rozporządzenie Ministra Rolnictwa i Rozwoju Wsi z dnia 9 marca 2015 r. w sprawie wyznaczenia trwałych użytków zielonych wartościowych pod względem środowiskowym; ${ }^{24}$ rozporządzenie Ministra Rolnictwa i Rozwoju Wsi z dnia 10 marca 2015 r. w sprawie warunków, jakie powinny spełniać jednostki organizacyjne, którym można powierzyć przeprowadzanie kontroli dotyczących płatności w ramach systemów wsparcia bezpośredniego; ${ }^{25}$ rozporządzenie Ministra Rolnictwa i Rozwoju Wsi z dnia 11 marca 2015 r. w sprawie obszarów uznawanych za obszary proekologiczne oraz warunków wspólnej realizacji praktyki utrzymania tych obszarów; ${ }^{26}$ rozporządzenie Ministra Rolnictwa i Rozwoju Wsi z dnia 12 marca 2015 r. w sprawie szczegółowych warunków i trybu przyznawania płatności bezpośrednich i płatności niezwiązanej do tytoniu; ${ }^{27}$ rozporządzenie Ministra Rolnictwa i Rozwoju Wsi z dnia 12 marca 2015 r. w sprawie szczegółowych wymagań, jakie powinny spełniać wnioski w sprawach dotyczących płatności

Ustawa z dnia 5 lutego 2015 r. o płatnościach w ramach systemów wsparcia bezpośredniego (Dz.U. poz. 308 z późn. zm.).

19 Rozporządzenie Ministra Rolnictwa i Rozwoju Wsi z dnia 6 marca 2015 r. w sprawie elementów krajobrazu uznawanych za część kwalifikującego się obszaru działki rolnej oraz ich szerokości (Dz.U. poz. 336). Rozporządzenie Ministra Rolnictwa i Rozwoju Wsi z dnia 6 marca 2015 r. w sprawie gatunków drzew, których uprawa stanowi zagajnik o krótkiej rotacji, oraz maksymalnego cyklu zbioru dla każdego z tych gatunków drzew (Dz.U. poz. 339).

Rozporządzenie Ministra Rolnictwa i Rozwoju Wsi z dnia 6 marca 2015 r. w sprawie określenia maksymalnego zagęszczenia drzew (Dz.U. poz. 338).

Rozporządzenie Ministra Rolnictwa i Rozwoju Wsi z dnia 6 marca 2015 r. w sprawie okresu obliczania udziału różnych upraw w celu dywersyfikacji upraw (Dz.U. poz. 340). Rozporządzenie Ministra Rolnictwa i Rozwoju Wsi z dnia 9 marca 2015 r. w sprawie norm w zakresie dobrej kultury rolnej zgodnej z ochroną środowiska (Dz.U. poz. 344). Rozporządzenie Ministra Rolnictwa i Rozwoju Wsi z dnia 9 marca 2015 r. w sprawie wyznaczenia trwałych użytków zielonych wartościowych pod względem środowiskowym (Dz.U. poz. 348).

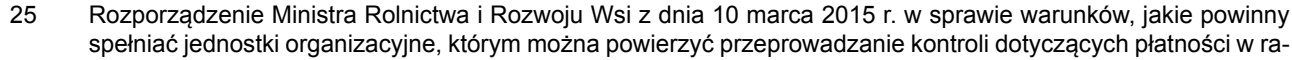
mach systemów wsparcia bezpośredniego (Dz.U. poz. 374). obszary proekologiczne oraz warunków wspólnej realizacji praktyki utrzymania tych obszarów (Dz.U. poz. 354). Rozporządzenie Ministra Rolnictwa i Rozwoju Wsi z dnia 12 marca 2015 r. w sprawie szczegółowych warunków i trybu przyznawania płatności bezpośrednich i płatności niezwiązanej do tytoniu (Dz.U. poz. 351). 
w ramach systemów wsparcia bezpośredniego ${ }^{28}$ i 7 innych szczegółowych rozporządzeń. Legislacja ta jest przede wszystkim aktami wykonawczymi do regulacji europejskich oraz polskiej ustawy, która stwarza ramy prawne dla funkcjonowania systemu płatności bezpośrednich po $2013 \mathrm{r}$.

Toczą się także prace legislacyjne nad regulacjami dotyczącymi realizacji polityki rozwoju obszarów wiejskich i wykonania zatwierdzonego przez Komisję Europejską Programu Rozwoju Obszarów Wiejskich na lata 2014-2020. W zakresie polityki rozwoju obszarów wiejskich wydano: ustawę z dnia 20 lutego 2015 r. o wspieraniu rozwoju obszarów wiejskich z udziałem środków Europejskiego Funduszu Rolnego na rzecz Rozwoju Obszarów Wiejskich w ramach Programu Rozwoju Obszarów Wiejskich na lata 2014-2020;29 ustawę z dnia 20 lutego 2015 r. o rozwoju lokalnym $z$ udziałem lokalnej społeczności; ${ }^{30}$ rozporządzenie Ministra Rolnictwa i Rozwoju Wsi z dnia 13 lipca 2015 r. w sprawie szczegółowych warunków i trybu przyznawania wypłaty oraz zwrotu pomocy finansowej na operacje typu „Premie dla młodych rolników” w ramach poddziałania „Pomoc w rozpoczęciu działalności gospodarczej na rzecz młodych rolników” objętego Programem Rozwoju Obszarów Wiejskich na lata 2014-2020; ${ }^{31}$ rozporządzenie Ministra Rolnictwa i Rozwoju Wsi z dnia 3 czerwca 2015 r. w sprawie szczegółowych warunków i trybu przyznawania pomocy finansowej w ramach poddziałania ,Wsparcie przygotowawcze" objętego Programem Rozwoju Obszarów Wiejskich na lata 2014-2020;32 rozporządzenie Ministra Rolnictwa i Rozwoju Wsi z dnia 29 maja 2015 r. zmieniające rozporządzenie w sprawie szczegółowych warunków i trybu przyznawania pomocy finansowej w ramach działania „Działanie rolnośrodowiskowo-klimatyczne” objętego Programem Rozwoju Obszarów Wiejskich na lata 2014-2020;33 rozporządzenie Ministra Rolnictwa i Rozwoju Wsi z dnia 8 maja 2015 r. w sprawie szczegółowych warunków i trybu przyznawania pomocy w ramach działania „Inwestycje w rozwój obszarów leśnych i poprawę żywotności lasów” objętego Programem

Rozporządzenie Ministra Rolnictwa i Rozwoju Wsi z dnia 12 marca 2015 r. w sprawie szczegółowych wymagań, jakie powinny spełniać wnioski w sprawach dotyczących płatności w ramach systemów wsparcia bezpośredniego (Dz.U. poz. 352).

Ustawa z dnia 20 lutego 2015 r. o wspieraniu rozwoju obszarów wiejskich z udziałem środków Europejskiego Funduszu Rolnego na rzecz Rozwoju Obszarów Wiejskich w ramach Programu Rozwoju Obszarów Wiejskich na lata 2014-2020 (Dz.U. poz. 349).

30 Ustawa z dnia 20 lutego 2015 r. o rozwoju lokalnym z udziałem lokalnej społeczności (Dz.U. poz. 378).

31 Rozporządzenie Ministra Rolnictwa i Rozwoju Wsi z dnia 13 lipca 2015 r. w sprawie szczegółowych warunków i trybu przyznawania, wypłaty oraz zwrotu pomocy finansowej na operacje typu „Premie dla młodych rolników” w ramach poddziałania „Pomoc w rozpoczęciu działalności gospodarczej na rzecz młodych rolników” objętego Programem Rozwoju Obszarów Wiejskich na lata 2014-2020 (Dz.U. poz. 982). Rozporządzenie Ministra Rolnictwa i Rozwoju Wsi z dnia 3 czerwca 2015 r. w sprawie szczegółowych warunków i trybu przyznawania pomocy finansowej w ramach poddziałania „Wsparcie przygotowawcze” objętego Programem Rozwoju Obszarów Wiejskich na lata 2014-2020 (Dz.U. poz. 851).

33 Rozporządzenie Ministra Rolnictwa i Rozwoju Wsi z dnia 29 maja 2015 r. zmieniające rozporządzenie w sprawie szczegółowych warunków i trybu przyznawania pomocy finansowej w ramach działania „Działanie rolnośrodowiskowo-klimatyczne” objętego Programem Rozwoju Obszarów Wiejskich na lata 2014-2020 (Dz.U. poz. 765). 
Rozwoju Obszarów Wiejskich na lata 2014-2020;34 rozporządzenie Ministra Rolnictwa i Rozwoju Wsi z dnia 18 marca 2015 r. w sprawie szczegółowych warunków i trybu przyznawania pomocy finansowej w ramach działania „Działanie rolnośrodowiskowo-klimatyczne" objętego Programem Rozwoju Obszarów Wiejskich na lata 2014-2020; ${ }^{35}$ rozporządzenie Ministra Rolnictwa i Rozwoju Wsi z dnia 13 marca 2015 r. w sprawie szczegółowych warunków i trybu przyznawania pomocy finansowej w ramach działania „Rolnictwo ekologiczne” objętego Programem Rozwoju Obszarów Wiejskich na lata 2014-2020;36 rozporządzenie Ministra Rolnictwa i Rozwoju Wsi z dnia 13 marca 2015 r. w sprawie szczegółowych warunków i trybu przyznawania pomocy finansowej w ramach działania „Płatności dla obszarów z ograniczeniami naturalnymi lub innymi szczególnymi ograniczeniami” objętego Programem Rozwoju Obszarów Wiejskich na lata 2014-2020. ${ }^{37}$

Trwają nadal prace nad przygotowaniem aktów wykonawczych dla wszystkich działań Programu Rozwoju Obszarów Wiejskich 2014-2020. Ich wydawanie związane jest z procedurą przydzielania poszczególnych środków finansowych i harmonogramem ustanowionym w programie.

Jednym z podstawowych zagadnień prawnych jest problematyka systemu płatności bezpośrednich. W Polsce obecnie istnieje około 1,5 mln gospodarstw rolnych uprawnionych do korzystania z systemu płatności bezpośrednich. W 2014 r. z tej podstawowej pomocy dla rolników korzystało około $1,4 \mathrm{mln} .{ }^{38}$ Rolnicy korzystają przede wszystkim z systemu płatności bezpośrednich, jako tego, który jest najmniej skomplikowany w procesie wnioskowania i przyznawania. ${ }^{39}$ Trzeba zwrócić uwagę, że wypracowane instrumenty prawne w ramach płatności bezpośrednich w Polsce

Rozporządzenie Ministra Rolnictwa i Rozwoju Wsi z dnia 8 maja 2015 r. w sprawie szczegółowych warunków i trybu przyznawania pomocy w ramach działania „Inwestycje w rozwój obszarów leśnych i poprawę żywotności lasów” objętego Programem Rozwoju Obszarów Wiejskich na lata 2014-2020 (Dz.U. poz. 655). Rozporządzenie Ministra Rolnictwa i Rozwoju Wsi z dnia 18 marca 2015 r. w sprawie szczegółowych warunków i trybu przyznawania pomocy finansowej w ramach działania „Działanie rolnośrodowiskowo-klimatyczne” objętego Programem Rozwoju Obszarów Wiejskich na lata 2014-2020 (Dz.U. poz. 415).

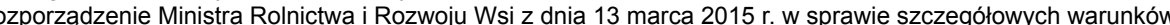
i trybu przyznawania pomocy finansowej w ramach działania „Rolnictwo ekologiczne” objętego Programem Rozwoju Obszarów Wiejskich na lata 2014-2020 (Dz.U. poz. 370).

37 Rozporządzenie Ministra Rolnictwa i Rozwoju Wsi z dnia 13 marca 2015 r. w sprawie szczegółowych warunków i trybu przyznawania pomocy finansowej w ramach działania „Płatności dla obszarów z ograniczeniami naturalnymi lub innymi szczególnymi ograniczeniami” objętego Programem Rozwoju Obszarów Wiejskich na lata 20142020 (Dz.U. poz. 364).

38 Gospodarstwa rolne na tle gospodarstw Unii Europejskiej - wpływ WPR, W. Poczta (red.), Warszawa 2013, s. 181-182.

39 W. Poczta, Change in agriculture with particular focus on structural transformations, [w:] J. Wilkin, I. Nurzyńska, Rural Poland 2012 Rural Development Report, Warszawa 2012, s. 82. 
były inne niż w krajach UE-15 ${ }^{40} \mathrm{w}$ ramach tzw. systemu uproszczonego. ${ }^{41}$ Sprzyja to w okresie przejściowym pozyskiwaniu pomocy, która pozwala na bieżące funkcjonowanie gospodarstwa rolnego. O obecnym poziomie rozdysponowania środków świadczą dane zawarte w poniższej tabeli.

Tabela 1. Liczba wydanych decyzji o przyznaniu płatności obszarowych w kampaniach 2004, 2005, 2006, 2007, 2008, 2009, 2010, 2011, 2012, 2013, 2014

\begin{tabular}{|c|c|c|c|c|c|c|c|c|c|c|c|}
\hline \multirow{2}{*}{ Województwo } & \multicolumn{11}{|c|}{ Liczba wydanych decyzji w kampanii } \\
\hline & 2004 & 2005 & 2006 & 2007 & 2008 & 2009 & 2010 & 2011 & 2012 & 2013 & 2014 \\
\hline DOLNOŚLĄSKIE & 60545 & 62488 & 61401 & 60550 & 58745 & 57565 & 57182 & 56403 & 56454 & 56307 & 56101 \\
\hline KUJAWSKO-POMORSKIE & 68594 & 69671 & 69048 & 68388 & 67348 & 66092 & 66137 & 65768 & 65695 & 65282 & 64492 \\
\hline LUBELSKIE & 172001 & 184725 & 183970 & 183489 & 180590 & 174967 & 175418 & 176869 & 177330 & 176416 & 175966 \\
\hline LUBUSKIE & 19978 & 21194 & 21117 & 21026 & 20504 & 20093 & 19912 & 19777 & 19855 & 19817 & 19740 \\
\hline ŁÓDZKIE & 126824 & 133476 & 132118 & 131052 & 128543 & 126417 & 125036 & 123157 & 122937 & 122065 & 121434 \\
\hline MAŁOPOLSKIE & 131023 & 141117 & 138930 & 136992 & 132085 & 126650 & 123446 & 121419 & 121259 & 120874 & 120915 \\
\hline MAZOWIECKIE & 206378 & 221132 & 219692 & 218277 & 213064 & 209057 & 207857 & 206042 & 206640 & 206163 & 205706 \\
\hline OPOLSKIE & 29994 & 30284 & 29611 & 29170 & 28607 & 27424 & 27688 & 27595 & 27734 & 27570 & 27456 \\
\hline PODKARPACKIE & 118357 & 130414 & 129034 & 127332 & 123672 & 119775 & 117517 & 116016 & 116590 & 116376 & 116326 \\
\hline PODLASKIE & 80289 & 84045 & 83775 & 83327 & 82463 & 81722 & 81255 & 80696 & 81010 & 80856 & 80650 \\
\hline POMORSKIE & 38621 & 40124 & 39824 & 39727 & 38960 & 37273 & 37974 & 38021 & 38404 & 38294 & 38411 \\
\hline ŚLASKIE & 52253 & 55768 & 54625 & 53915 & 51783 & 49533 & 48509 & 47646 & 47483 & 47187 & 47075 \\
\hline ŚWIĘTOKRZYSKIE & 91322 & 95980 & 95078 & 94045 & 91621 & 87989 & 86912 & 85526 & 85280 & 84834 & 84614 \\
\hline WARMIŃSKO-MAZURSKIE & 41443 & 43625 & 43768 & 43713 & 42951 & 42623 & 42758 & 42759 & 43130 & 43100 & 43101 \\
\hline WIELKOPOLSKIE & 121667 & 125194 & 124290 & 123837 & 122353 & 120546 & 120686 & 120490 & 121116 & 120840 & 120341 \\
\hline ZACHODNIOPOMORSKIE & 28553 & 29739 & 29479 & 29386 & 28470 & 27967 & 27898 & 27945 & 28370 & 28460 & 28533 \\
\hline Razem & 1387842 & 1468976 & 1455760 & 1444226 & 1411759 & 1375693 & 1366185 & 1356129 & 1359287 & 1354441 & 1350861 \\
\hline
\end{tabular}

Źródto: Opracowanie własne na podstawie: System Informacji Zarzqdczej ARiMR, data sporzqdzenia: maj $2015 \mathrm{r}$.

40 J. Bieluk, D. Łobos-Kotowska, Płatności bezpośrednie, [w:] P. Czechowski (red.), Prawo rolne, Warszawa 2011, s. 407; A. Germano, Reforma Wspólnej Polityki Rolnej z 2003 r. i reżim płatności jednolitej, „Przegląd Prawa Rolnego", 2007, nr 1; T. Kurowska, Zadania i funkcje instrumentów prawnych wspierania rozwoju obszarów wiejskich, [w:] „Studia luridica Agraria” 2005, t. IV; A. Jurcewicz, B. Kozłowska, E. Tomkiewicz, Wspólna Polityka Rolna. Zagadnienia prawne, Warszawa, 2006; D. Milanowska, Instrument modulacji w nowym systemie dopłat bezpośrednich, „Studia luridica Agraria” 2007, t. VI; S. Prutis, Instrumenty prawne wsparcia rozwoju rolnictwa ze środków UE (w świetle orzecznictwa Wojewódzkiego Sądu Administracyjnego w Białymstoku), „Studia luridica Agraria” 2007, t. VI; A. Oleszko, „Dziedziczenie” kwot produkcyjnych oraz płatności w rolnictwie, „Annales Universitatis Mariae Curie-Skłodowska", Lublin-Polonia, vol. LII/LIII, sectio G, 2005-2006.

41 B. Wieliczko, Mechanizmy oddziaływania funduszy strukturalnych na konkurencyjność polskiego rolnictwa, „Studia luridica Agraria" 2012, t. X, s. 443-457; J. Mikołajczyk, Współczesne funkcje obszarów wiejskich na tle koncepcji multifunkcjonalnego rolnictwa, „Studia luridica Agraria” 2012, t. X, s. 367-384. 
Nowością w systemie płatności bezpośrednich jest uwzględnienie w systemie pomocy finansowej ze środków europejskich wdrażania tzw. polityki zazieleniania. ${ }^{42}$ Wiąże się ona bezpośrednio ze zwiększeniem roli czynników mających wpływ na wzrost poziomu ochrony środowiska naturalnego w procesie produkcji rolnej. Wprowadzenie polityki zazieleniania znalazło swoje odzwierciedlenie w rozporządzeniu Parlamentu Europejskiego i Rady (UE) nr 1307/2013 z dnia 17 grudnia 2013 r. ustanawiającym przepisy dotyczące płatności bezpośrednich dla rolników na podstawie systemów wsparcia w ramach wspólnej polityki rolnej oraz uchylające rozporządzenie Rady (WE) nr 637/2008 i rozporządzenie Rady (WE) nr 73/2009. ${ }^{43}$ Określa ono odpowiednie obowiązki, które musi spełnić rolnik, aby móc ubiegać sie o jedną z podstawowych form pomocy w postaci płatności bezpośrednich. ${ }^{44} \mathrm{Re}$ gulacje te dotyczą każdego rolnika, który może ubiegać się o taką pomoc. Nieznane są jeszcze efekty wprowadzenia nowych wymagań i ich korelacji z rozdziałem tych środków, w szczególności na obszarach Natura 2000.

Z pomocy pochodzącej z funduszy europejskich przeznaczonych dla rolnictwa korzysta ok. $71 \%$ uprawnionych podmiotów. ${ }^{45}$ Obecnie akceptacja polityczna, jak również społeczna dla tej pomocy rolnictwu poprzez system dofinansowywania jest duża. Sprzyja temu wzrost konkurencyjności polskiego rolnictwa, również dzięki udziałowi środków europejskich. ${ }^{46}$ Wszystkie ugrupowania parlamentarne w różnym stopniu (pięć partii politycznych) popierają dotowanie wskazanych w przepisach europejskich sektorów rolnictwa oraz rynku rolnego. ${ }^{47}$ Problemem staje się jednakże spełnienie przez część rolników wymogów stawianych w reformie Wspólnej Polityki Rolnej z 2013 r. ${ }^{48}$ Dotyczy to w szczególności praktyk korzystnych dla klimatu. ${ }^{49}$ Praktyki te wprowadzone po reformie WPR w 2013 r. stanowią nowe wyzwanie dla polskich rolników, którzy będą musieli w większym stopniu uwzględniać

B. Jeżyńska, R. Pastuszko, Pakiet legislacyjny WPR 2014-2020 w świetle podstaw prawa UE i prawa międzynarodowego. Kompleksowa analiza prawna, Biuro Analiz i Dokumentów, OE - 186, marzec 2012.

Dz.U. UE L z 2013 r. Nr 347, poz. 608 z późn. zm.

B. Jeżyńska, Znaczenie i funkcje zasady cross-compliance w systemie rolniczych dopłat bezpośrednich, „Studia luridica Lubliniensia" 2010, nr 13, s. 35-50.

http://www.minrol.gov.pl/Wsparcie-rolnictwa-i-rybolowstwa/Platnosci-bezposrednie

P. Cichalewska, S, Brodecki, Wpływ Programu Rozwoju Obszarów Wiejskich 2007-2013 na konkurencyjność polskiego rolnictwa, „Studia luridica Agraria” 2012, t. X, s. 355-365.

Główne głosowania w sprawie rolnictwa oraz programy polityczne partii parlamentarnych wskazują na akceptację polityczną podstawowej polityki rolnej. Wyjątkiem jest tutaj jedna z lewicowych partii politycznych, która w dużym stopniu nie akceptuje uprzywilejowania rolnictwa i rolników, dotyczy to m.in. dotowania produkcji, czy odrębnego systemu ubezpieczeń społecznych rolników w Polsce (http://twojruch.eu/wp-content/uploads/2014/09/ plan-zmian.pdf, s. 33).

W. Czubak, W. Poczta, A. Sadowski, Wpływ proponowanej reformy systemu dopłat bezpośrednich po 2013 roku na sytuację polskiego rolnictwa, „Wieś i rolnictwo” 2011, nr 4.

B. Jeżyńska, R. Pastuszko, Pakiet legislacyjny WPR 2014-2020...,op.cit., Biuro Analiz i Dokumentów, OE - 186, marzec 2012; B. Jeżyńska, Znaczenie i funkcje zasady cross-compliance..., op.cit., s. 35-50; A. Niewiadomski, Europejska Sieć Ekologiczna Natura 2000 a zrównoważony rozwój obszarów wiejskich, „Studia luridica Agraria” 2013, t. XI, s. 293-304; E. Tomkiewicz, M. Bocheński, Polityka rozwoju obszarów wiejskich w perspektywie lat 2014-2020 w kontekście nowych wyzwań, „Studia luridica Agraria” 2012, t. X, s. 239-250. 
w procesie produkcji rolnej czynnik ochrony środowiska naturalnego. ${ }^{50}$ Społeczna akceptacja dla pomocy dla rolnictwa ze środków europejskich widoczna jest także $\mathrm{w}$ innych grupach społecznych niż rolnicy. ${ }^{51}$

Zgodnie z prowadzonymi przez polski rząd badaniami ,ze względu na miejsce zamieszkania, największy odsetek nierolników dostrzegających zmiany na lepsze w polskim rolnictwie występuje w regionie południowo-zachodnim (37\%). W tym regionie występuje jednak największy odsetek rolników, którzy oceniają zmiany w polskim rolnictwie negatywnie (50\%). Największy odsetek rolników dostrzegających zmiany na lepsze odnotowano natomiast w regionie południowym $(45 \%)$. Odsetek badanych rolników negatywnie oceniających przemiany w polskim rolnictwie spadł w porównaniu z latami poprzednimi (w porównaniu do roku $2013 \mathrm{spadł}$ o 10 punktów procentowych, w porównaniu z rokiem 2010 o 23 punkty procentowe). Wzrósł natomiast odsetek respondentów dostrzegających zmiany na lepsze, co może świadczyć o pozytywnym kierunku zmian w tym zakresie. Największy odsetek rolników dostrzegających zmiany na lepsze w polskim rybactwie ma region południowy (30\%). W tym regionie odnotowano również największy odsetek nierolników dostrzegających zmiany na lepsze w tym obszarze (24\%). Wyniki badań pokazują, że z roku na rok wzrasta odsetek respondentów oceniających zmiany zachodzące w polskim rybactwie pozytywnie. Natomiast w przypadku odsetka badanych dostrzegających zmiany na gorsze nie występuje wyraźny trend". ${ }^{52}$

Udział pomocy pochodzącej ze środków UE w dochodowości polskich gospodarstw kształtuje się różnie w zależności od wielkości gospodarstwa, specyfikacji produkcji, możliwości uzyskania pomocy. Te czynniki wpływają na strukturę wydatkowych środków, a co za tym idzie na dochodowość gospodarstw. Zgodnie z raportem „Polska wieś i rolnictwo w 2014 r.” rolnicy środki pochodzące z płatności bezpośrednich przeznaczają najczęściej na zakup paliwa do produkcji rolnej (24\%), zakup nawozów i środków ochrony roślin (38\%), zakup maszyn rolniczych $(25 \%)$, budowa lub remont budynku mieszkalnego (12\%). ${ }^{53}$

Na pomocy pochodzącej z funduszy europejskich korzystają przede wszystkim właściciele i posiadacze gospodarstw rolnych małych i średnich. ${ }^{54}$ Fundusze te pozwalają zwiększyć im poziom inwestycji, a co za tym idzie osiągnąć większy dochód. ${ }^{55}$ Największy udział środków pochodzących $\mathrm{z}$ finansowania WPR w docho-

50 B. Jankowski, Oddziaływanie Wspólnej Polityki Rolnej na ochronę środowiska, „Studia luridica Agraria” 2012 , t. X, s. 515-525; B. Jeżyńska, Proekologiczne instrumenty wsparcia zrównoważonego rozwoju obszarów Wiejskich, „Studia luridica Agraria” 2012, t. X, s. 251-264.

51 Public opinion in the European Union, Eurobarometr 2014, s. 77-120.

52 Polska wieś i rolnictwo 2014, s. 107.

53 Ibidem, s. 29.

54 P. Wojciechowski, Postępowanie dotyczące przyznawania pomocy finansowej w ramach działań objętych Programem Rozwoju Obszarów Wiejskich, „Studia luridica Agraria” 2012, t. X, s. 335-354. 
dach rolniczych dotyka gospodarstw, których wielkość ekonomiczna nie przekracza 4 ESU. Obecnie udział tych środków w dochodach rolniczych w tych gospodarstwach to ok. 35\%. ${ }^{56}$ Gospodarstwa te w znacznej mierze są głównymi beneficjentami pomocy i to ich właściciele oraz posiadacze mogliby najwięcej stracić w przypadku likwidacji obecnego systemu wsparcia dla rolnictwa ze środków europejskich.

Im większe obszarowo gospodarstwo, tym udział środków europejskich w dochodach rolniczych maleje (gospodarstwa 4-8 ESU - 24,6\%, 8-16 ESU - 17,8\%, 16-40 ESU - 14,3\%, 40-100 ESU - 13,2\%; powyżej 100 ESU - 7,1\%). ${ }^{57}$ Zgodnie z danymi rządowymi „43\% badanych mieszkańców wsi wskazuje, że sytuacja finansowa ich gospodarstwa domowego jest dobra lub bardzo dobra. Przeciwnego zdania jest $15 \%$ respondentów. Odsetek mieszkańców wsi oceniających pozytywnie sytuację materialną wzrósł w porównaniu do wszystkich poprzednich analizowanych okresów". ${ }^{58}$ Szacuje się, że zmiany WPR i mniejsze środki pomocowe po 2013 r. mogą obniżyć powyższe wielkości.

Kolejnym problemem praktycznym i ekonomicznym jest likwidacja kwot mlecznych, która dla polskiego rolnictwa oznacza pewną rewolucję. ${ }^{59}$ Oznacza przede wszystkim liberalizację rynku mleka w Polsce. Sprzyja również poprawie konkurencyjności pośród producentów mleka, bo o popycie na mleko będzie decydować już jakość, cena produktu, a nie system specjalnych kwot. ${ }^{60}$ Obecnie polska branża mleczarska wymaga modernizacji i przyspieszenia jej rozwoju, w celu specjalizacji produkcji mleka. Likwidacja kwot mlecznych może temu sprzyjać. ${ }^{61}$ Poszczególni producenci mleka powinni zwiększyć dochodowość swoich gospodarstw w wyniku sprzedaży większej ilości mleka. Będzie to zależne jednakże od skali produkcji, specjalizacji i poziomu nowych inwestycji w ten sektor i poszczególne gospodarstwa.

Wiąże się ona także z dużą reorganizacją rynku mleka w Polsce. ${ }^{62}$ Minister Rolnictwa i Rozwoju Wsi w jednym z wywiadów prasowych wskazał, że ,będzie miało

na przykładzie gospodarstw wysokotowarowych. Raport nr 10, Warszawa 2005; idem, Gospodarstwa wysokotowarowe w rolnictwie chłopskim. Synteza wyników badań 2005-2009, Warszawa 2009, s. 27. 2015, s. 32-33.

57 Charakterystyka gospodarstw rolnych w 2013 r., op.cit., s. 138-142; Rolnictwo w 2014 r., op.cit., s. 32-33.

58 Polska wieś i rolnictwo 2014, s. 41.

59 A. Baer-Nawrocka, E. Kiryluk-Dryjska, Wpływ likwidacji kwot mlecznych na sytuację produkcyjną i ekonomiczna producentów mleka w Unii Europejskiej (wyniki symulacji modelowych), „Wieś i Rolnictwo” 2010, nr 3.

60 P. Szajner, Wpływ likwidacji kwot mlecznych i zmian regulacji rynku mleka na perspektywy rozwoju polskiego mleczarstwa, s. 12; P. Szajner, Ocena wpływu likwidacji kwot mlecznych na konkurencyjność polskiego mleczarstwa w kontekście teorii ekonomii, „Zeszyty Naukowe Szkoły Głównej Gospodarstwa Wiejskiego w Warszawie. Problemy Rolnictwa Światowego“ 2012, nr 12(27), s. 104-112.

61 Stan przygotowania Polski i Unii Europejskiej do zniesienia kwot mlecznych, D. Ogryczak (red.), Warszawa 2014.

62 M. Karolewska, Polskie duże gospodarstwa specjalizujące się w produkcji mleka na tle gospodarstw z wybranych krajów europejskich, „Roczniki Naukowe Rolnictwa” 2006, Seria G, nr 93,1; D. Komorowska, Koncentracja produkcji mleka w Polsce, „Zeszyty Naukowe Ekonomiki Organizacji Gospodarki Żywnościowej” 2006, nr 61. 
miejsce szukanie dobrych dostawców i producentów przez duże zakłady przetwórcze, co stanowi duże zagrożenie dla małych zakładów mleczarskich". ${ }^{63}$ W wyniku takich zmian, jeżeli małe przetwórnie mleczne szybko nie dostosują swojej oferty do potrzeb rynku, to będą zagrożone wypadnięciem z rynku. Przewiduje się, że likwidacja kwoty mlecznej będzie sprzyjać konsolidacji rynku, w szczególności tworzeniu większych zakładów przetwórczych, które będą w stanie odbierać od rolników wyprodukowane mleko. Likwidacja kwot mlecznych może oznaczać spadek rentowności małych producentów, którzy dzięki temu systemowi mogli mieć jakikolwiek zysk z produkcji mleka. ${ }^{64}$

Należy również zwrócić uwagę, że likwidacji uległ mechanizm kontrolujący rynek mleka i ilości wytwarzane przez poszczególnych producentów. Z punktu widzenia liberalizacji rynku taki fakt należy przyjąć z zadowoleniem, natomiast z punktu widzenia jakości produkcji, należy wzmocnić kontrole odpowiednich służb weterynaryjnych.

Pewnym ubocznym problemem związanym z likwidacją kwot mlecznych może być także wzrost pogłowia bydła mlecznego. Może to spowodować znaczne zmiany na rynku wołowiny poprzez wzrost podaży tych produktów. ${ }^{65}$

Obecnie w Polsce realizowany jest system kontroli przyznawanych środków zgodnie z regulacjami europejskimi. Jedną z podstaw prawnych kontroli jest rozporządzenie Parlamentu Europejskiego i Rady (UE) nr 1306/2013 z dnia 17 grudnia 2013 r. w sprawie finansowania wspólnej polityki rolnej, zarządzania nią i monitorowania jej oraz uchylające rozporządzenia Rady (EWG) nr 352/78, (WE) nr 165/94, (WE) nr 2799/98, (WE) nr 814/2000, (WE) nr 1290/2005 i (WE) nr 485/200866 (w szczególności art. 79-90) oraz szczegółowe akty prawne dotyczące różnych możliwych typów kontroli.

W tym zakresie polska agencja płatnicza (w Polsce Agencja Restrukturyzacji i Modernizacji Rolnictwa) przeprowadza szereg kontroli, m.in. kontrolę na miejscu, kontrole krzyżowe, kontrole formalne, ${ }^{67}$ kontrole cross-compliance, kontrole norm i wymogów wzajemnej zgodności, kontrole w ramach Programu Rozwoju Obszarów Wiejskich, kontrole płatności bezpośrednich, kontrole siedzib stad.

63 Wywiad z Ministrem Rolnictwa i Rozwoju Wsi dr. Markiem Sawickim http://www.money.pl/gospodarka/wiadomosci/artykul/kwoty-mleczne-odchodza-do-lamusa-dzis,96,0,1749088.html

64 M. Sznajder, Skutki likwidacji kwot mlecznych dla mleczarstwa polskiego, Opinie i ekspertyzy. Kancelaria Senatu, Warszawa 2010.

65 B. Czyżewski, M. Śmigala, Instytucjonalne przesłanki rozwoju gospodarstw mleczarskich w Polsce, „Journal of Agribusiness and Rural Development" 2012, nr 3(25), s. 81-99.

66 Rozporządzenie Parlamentu Europejskiego i Rady (UE) nr 1306/2013 z dnia 17 grudnia 2013 r. w sprawie finansowania wspólnej polityki rolnej, zarządzania nią i monitorowania jej oraz uchylające rozporządzenia Rady (EWG) nr 352/78, (WE) nr 165/94, (WE) nr 2799/98, (WE) nr 814/2000, (WE) nr 1290/2005 i (WE) nr 485/2008 (Dz.Urz. UE L 347 z dnia 20 grudnia 2013 r., s. 549 z późn. zm.).

67 P. Wojciechowski, Odpowiedzialność administracyjna i karna beneficjentów pomocy z Programu Rozwoju Ob- 
Ewentualne wykryte nieprawidłowości są usuwane, a naruszenia przepisów prawa i zasad przyznawania pomocy są karane zgodnie z regulacjami dotyczącymi poszczególnych pomocy. Polska $\mathrm{w}$ tym zakresie zwraca zgodnie z regulacjami europejskimi niewłaściwie wydatkowane środki finansowe. Obecnie istnieją pewne szczegółowe problemy dotyczące systemu kontroli wydatkowania środków pomocowych pochodzących z funduszy europejskich przeznaczonych na rolnictwo. ${ }^{68} \mathrm{Nie}$ mają one jednak charakteru generalnego i większość wydatkowanych środków w ramach funduszy europejskich odbywa się poprawnie.

Ponadto przyznawanie środków, które odbywa się w drodze umów, kontrolowane jest w drodze postępowania cywilnoprawnego ${ }^{69}$ Nadzór nad wykonaniem tych umów sprawują nie tylko ich strony, ale także sądy powszechne w Polsce.

Wnioski o finansowanie pomocy składane są przez specjalny system teleinformatyczny polskiej agencji płatniczej ${ }^{70}$ - Agencji Restrukturyzacji i Modernizacji Rolnictwa. Pozwala to na szybsze publikowanie listy osób, które otrzymały pomoc. ${ }^{71}$ Po uzyskaniu pomocy listy beneficjentów publikowane są w specjalnej bazie on-line beneficjentów pomocy Wspólnej Polityki Rolnej. ${ }^{72}$ Taki sposób publikacji o beneficjentach ułatwia transparentność i jawność całego procesu przyznawania pomocy. Zakres udostępnianych danych określają rozporządzenie Parlamentu Europejskiego i Rady (UE) nr 1306/2013 z dnia 17 grudnia 2013 r. w sprawie finansowania wspólnej polityki rolnej, zarządzania nią i monitorowania jej ${ }^{73}$ oraz rozporządzenie Komisji (UE) nr 908/2014 z dnia 6 sierpnia 2014 r. ustanawiające zasady dotyczące stosowania rozporządzenia Parlamentu Europejskiego i Rady (UE) nr 1306/2013 w odniesieniu do agencji płatniczych i innych organów, zarządzania finansami, rozliczania rachunków, przepisów dotyczących kontroli, zabezpieczeń i przejrzystości. ${ }^{74}$

Polska agencja płatnicza (Agencja Restrukturyzacji i Modernizacji Rolnictwa) publikuje sprawozdania o zakresie udzielonej pomocy (wysokości wnioskowanych kwot oraz wysokości udzielonej pomocy) oraz o liczbie wnioskodawców i benefi-

68

A. Niewiadomska, A. Niewiadomski, Structural Funds of Polish Agriculture, „World Academy of Science, Engineering and Technology" 2012, issue 71, s. 1804-1810.

D. Łobos-Kotowska, Umowa przyznania pomocy z Europejskiego Funduszu Rolnego na rzecz Rozwoju Obszarów Wiejskich a inne podobne umowy, „Studia luridica Agraria” 2012, t. X, s. 265-280.

A. Niewiadomski, P. Wojciechowski, Program Rozwoju Obszarów Wiejskich, [w:] Prawo rolne, P. Czechowski (red)., Warszawa 2011, s. 419 i nast.

W. Czubak, A. Sadowski, Dostępność informacji oraz czynniki utrudniające ubieganie się o dopłaty bezpośrednie, „Wieś i Rolnictwo” 2010, nr 3.

http://beneficjenciwpr.minrol.gov.pl/

Rozporządzenie Parlamentu Europejskiego i Rady (UE) nr 1306/2013 z dnia 17 grudnia 2013 r. w sprawie finansowania wspólnej polityki rolnej, zarządzania nią i monitorowania jej (Dz.Urz. UE L 347 z dnia 20 grudnia 2013 r., s. 549).

Rozporządzenie Komisji (UE) nr 908/2014 z dnia 6 sierpnia 2014 r. ustanawiające zasady dotyczące stosowania rozporządzenia Parlamentu Europejskiego i Rady (UE) nr 1306/2013 w odniesieniu do agencji płatniczych i innych organów, zarządzania finansami, rozliczania rachunków, przepisów dotyczących kontroli, zabezpieczeń i przejrzystości (Dz.Urz. UE L 255 z dnia 28 sierpnia 2014 r., s. 59). 
cjentów. Szczegółowo przekazywane są dane dotyczące informacji o beneficjentach pomocy z uwzględnieniem wielu kryteriów, m.in.: wielkości gospodarstwa, rodzaju produkcji, wielkości ekonomicznej gospodarstwa, struktury gospodarstwa. ${ }^{75}$ Ponadto w systemach konkursowych publikowane są listy rankingowe wnioskodawców.

Zasygnalizowane powyżej problemy prawne związane z funkcjonowaniem nowych aktów prawnych pozwalają wskazać na koniczność lepszej koordynacji podejmowanych zamierzeń legislacyjnych, przede wszystkim w zakresie dostosowania tempa wydawania aktów prawnych do prowadzonych naborów wniosków na kolejne działania pomocowe.

W tym zakresie na uwagę zasługuje nowe podejście do polityki płatności bezpośrednich, w której uwzględnia się politykę „zazieleniania”. Powstaje pytanie, czy ta słuszna idea dbania o środowisko naturalne przekona rolników do korzystania $\mathrm{z}$ pomocy z funduszy europejskich w zamian ze pewną reorganizację części swojej produkcji rolnej. Współczesny system zachęt dla rolników może okazać się niewystarczający. 
THE COMMON AGRICULTURAL POLICY AFTER 2013.

- FEATURED LEGAL PROBLEMS

\author{
budget \\ Keywords: Common Agricultural Policy, financing instruments, Community
}

Reform of the Common Agricultural Policy introduced from 2013 shows the new financial perspectives for agriculture sustainable agriculture preferring to operate in accordance with the principles of nature conservation. To that end, the CAP financing instruments created many new requirements and incentives for farmers. Some of the existing mechanisms have been modified and adapted to the new objectives of the CAP and the possibility of the Community budget. Below are presented the most important legal issues in terms of implementation and application of the new provisions concerning the financing of the CAP.

\title{
Bibliografia:
}

A. Baer-Nawrocka, E. Kiryluk-Dryjska, Wpływ likwidacji kwot mlecznych na sytuację produkcyjną i ekonomiczną producentów mleka w Unii Europejskiej (wyniki symulacji modelowych), „Wieś i Rolnictwo” 2010, nr 3.

J. Bieluk, D. Łobos-Kotowska, Płatności bezpośrednie, [w:] P. Czechowski (red.), Prawo rolne, Warszawa 2011.

Charakterystyka gospodarstw rolnych w 2013 r., Warszawa 2014.

P. Cichalewska, S. Brodecki, Wpływ Programu Rozwoju Obszarów Wiejskich 2007-2013 na konkurencyjność polskiego rolnictwa, „Studia Iuridica Agraria” 2012, t. X.

P. Czechowski, A. Niewiadomski, Obszary wiejskie a planowanie przestrzenne, „Studia Iuridica Agraria" 2012, t. X.

P. Czechowski, A. Niewiadomski, Wpływ funduszy strukturalnych na wzrost konkurencyjności polskiego rolnictwa - aspekty prawne, „Studia Iuridica Agraria” 2012, t. X.

W Czubak, W. Poczta, A. Sadowski, Wpływ proponowanej reformy systemu dopłat bezpośrednich po 2013 roku na sytuację polskiego rolnictwa, „Wieś i Rolnictwo” 2011, nr 4.

W Czubak, A. Sadowski, Dostępność informacji oraz czynniki utrudniające ubieganie się o dopłaty bezpośrednie, „Wieś i Rolnictwo” 2010, nr 3.

B. Czyżewski, M. Śmigala, Instytucjonalne przesłanki rozwoju gospodarstw mleczarskich w Polsce, „Journal of Agribusiness and Rural Development” 2012, nr 3(25).

W. Dzun, Duże gospodarstwa rolne przed i po wejściu do UE, [w:] Polska wieś i rolnictwo w Unii Europejskiej. Dylematy i kierunki przemian, Warszawa 2008.

A. Germano, Reforma Wspólnej Polityki Rolnej z 2003 r. i reżim płatności jednolitej, „Przegląd Prawa Rolnego" 2007, nr 1.

Gospodarstwa rolne na tle gospodarstw Unii Europejskiej - wpływ WPR, W. Poczta (red.), Warszawa 2013. 
B. Jankowski, Oddziaływanie Wspólnej Polityki Rolnej na ochronę środowiska, „Studia Iuridica Agraria" 2012, t. X.

B. Jeżyńska, R. Pastuszko, Pakiet legislacyjny WPR 2014-2020 w świetle podstaw prawa UE i prawa międzynarodowego. Kompleksowa analiza prawna, Biuro Analiz i Dokumentów, OE - 186, marzec 2012.

B. Jeżyńska, Proekologiczne instrumenty wsparcia zrównoważonego rozwoju obszarów Wiejskich, „Studia Iuridica Agraria” 2012, t. X.

B. Jeżyńska, Znaczenie i funkcje zasady cross-compliance w systemie rolniczych dopłat bezpośrednich, „Studia Iuridica Lubliniensia” 2010, nr 13.

W. Józwiak, W. Michna, Z. Mirkowska, Procesy zachodzące w polskim rolnictwie w latach 1990-2010 i pożądana wizja rolnictwa w 2020 roku - zagadnienia wybrane, Warszawa 2011.

A. Jurcewicz, B. Kozłowska, E. Tomkiewicz, Wspólna Polityka Rolna. Zagadnienia prawne, Warszawa 2006.

A. Jurcewicz, Wspólna Polityka Rolna Unii Europejskiej, [w:] Prawo rolne, P. Czechowski (red)., Warszawa 2011.

M. Karolewska, Polskie duże gospodarstwa specjalizujące się w produkcji mleka na tle gospodarstw z wybranych krajów europejskich, ,,Roczniki Naukowe Rolnictwa” 2006, Seria G, nr 93,1.

B. Karwat-Woźniak, Możliwości rozwojowe chłopskiego rolnictwa na przykładzie gospodarstw wysokotowarowych. Raport nr 10, Warszawa 2005.

B. Klepacki, Wykształcenie jako czynnik różnicujący zasoby, organizację i wyniki ekonomiczne gospodarstw rolniczych, 2005.

D. Komorowska, Koncentracja produkcji mleka w Polsce, [w:] „Zeszyty Naukowe Ekonomiki Organizacji Gospodarki Żywnościowej”, 2006, nr 61.

M.A Król, Model doradztwa rolniczego w Polsce na tle rozwiązań przyjętych w wybranych krajach członkowskich Unii Europejskiej, Warszawa 2013.

T. Kurowska, Zadania i funkcje instrumentów prawnych wspierania rozwoju obszarów wiejskich, „Studia Iuridica Agraria” 2005, t. IV.

T. Kurowska, Założenia konstrukcyjne umowy przyznania pomocy z Europejskiego Funduszu Rolnego na rzecz Rozwoju Obszarów Wiejskich, „Studia Iuridica Agraria” 2009, t. VII.

D. Łobos-Kotowska, Umowa przyznania pomocy z Europejskiego Funduszu Rolnego na rzecz Rozwoju Obszarów Wiejskich a inne podobne umowy, ,Studia Iuridica Agraria” 2012, t. X.

J. Mikołajczyk, Współczesne funkcje obszarów wiejskich na tle koncepcji multifunkcjonalnego rolnictwa, ,Studia Iuridica Agraria” 2012, t. X.

D. Milanowska, Instrument modulacji w nowym systemie dopłat bezpośrednich, „Studia Iuridica Agraria" 2007, t. VI.

A. Niewiadomska, A. Niewiadomski A., Structural Funds of Polish Agriculture, „World Academy of Science, Engineering and Technology” 2012, issue 71.

A. Niewiadomski, Europejska Sieć Ekologiczna Natura 2000 a zrównoważony rozwój obszarów wiejskich, „Studia Iuridica Agraria” 2013, t. XI.

A. Niewiadomski, P. Wojciechowski, Program Rozwoju Obszarów Wiejskich, [w:] Prawo rolne, P. Czechowski (red.), Warszawa 2011.

A.Z. Nowak, A. Niewiadomska, Wpływ funduszy strukturalnych na wzrost konkurencyjności polskiego rolnictwa - wybrane aspekty ekonomiczne, „Studia Iuridica Agraria” 2012, t. X. 
A. Oleszko, ,Dziedziczenie” kwot produkcyjnych oraz płatności w rolnictwie, [w:] „Annales Universitatis Mariae Curie-Skłodowska”, Lublin-Polonia, vol. LII/LIII, sectio G, 2005-2006.

W. Poczta, Change in agriculture with particular focus on structural transformations [w:] J. Wilkin, I. Nurzyńska, Rural Poland 2012 Rural Development Report, Warszawa 2012.

W. Poczta, Wspólna Polityka Rolna po 2013 roku - wizja zmian, [w:] red. A. Czyżewski, W. Poczta, Projekty inwestycyjne w agrobiznesie a zasady Wspólnej Polityki Rolnej po 2013 roku, Poznań 2011.

Polska wieś i rolnictwo 2014.

S. Prutis, Dobór instrumentów prawnych służących wsparciu rozwoju obszarów wiejskich, „Studia Iuridica Agraria" 2009, t. VII.

S. Prutis, Instrumenty prawne wsparcia rozwoju rolnictwa ze środków UE (w świetle orzecznictwa Wojewódzkiego Sądu Administracyjnego w Białymstoku), „Studia Iuridica Agraria” 2007, t. VI.

Rolnictwo w 2014 r., Warszawa 2015.

Stan przygotowania Polski i Unii Europejskiej do zniesienia kwot mlecznych, red. D. Ogryczak, Warszawa 2014.

J. Stoksik, Wybrane zagadnienia ochrony interesów finansowych Unii Europejskiej w dziedzinie Wspólnej Polityki Rolnej, „Studia Iuridica Agraria” 2012, t. X.

P. Szajner, Ocena wpływu likwidacji kwot mlecznych na konkurencyjność polskiego mleczarstwa w kontekście teorii ekonomii, „Zeszyty Naukowe Szkoły Głównej Gospodarstwa Wiejskiego w Warszawie. Problemy Rolnictwa Światowego“, 2012, nr 12(27).

P. Szajner, Wpływ likwidacji kwot mlecznych i zmian regulacji rynku mleka na perspektywy rozwoju polskiego mleczarstwa, IERiGŻ.

M. Sznajder, Skutki likwidacji kwot mlecznych dla mleczarstwa polskiego, Opinie i ekspertyzy. Kancelaria Senatu, Warszawa 2010.

E. Tomkiewicz, Bocheński M., Polityka rozwoju obszarów wiejskich w perspektywie lat 2014-2020 w kontekście nowych wyzwań, „Studia Iuridica Agraria” 2012, t. X.

B. Wieliczko, Mechanizmy oddziaływania funduszy strukturalnych na konkurencyjność polskiego rolnictwa, ,Studia Iuridica Agraria” 2012, t. X.

J. Wilkin, Wielofunkcyjność rolnictwa - konceptualizacja i operacjonalizacja zjawiska, [w:] „Wieś i Rolnictwo", 2009, $\mathrm{nr} 4$.

P. Wojciechowski, Odpowiedzialność administracyjna i karna beneficjentów pomocy z Programu Rozwoju Obszarów Wiejskich, ,Studia Iuridica Agraria” 2012, t. X.

P. Wojciechowski, Postępowanie dotyczące przyznawania pomocy finansowej w ramach działań objętych Programem Rozwoju Obszarów Wiejskich, ,Studia Iuridica Agraria” 2012, t. X. 